\title{
Effect of Cissus quadrangularis on Fracture Healing in Laboratory Animal
}

\section{Efeito do Cissus quadrangularis na cicatrização de fraturas em animais de laboratório}

\author{
Mst Nusrat Zahan ${ }^{1,2}$ (D), Moinul Hasan² (1) , Sourav Mallick² (D), Mirza Abul Hashem² (D), Nasrin Sultana Juyena² (1)
}

1. Department of Surgery and Theriogenology, Sher-e-Bangla Agricultural University, Dhaka -1207, Bangladesh. 2. Department of Surgery and Obstetrics, Bangladesh Agricultural University, Mymensingh-2202, Bangladesh.

\begin{abstract}
Objectives: The present study was designed to examine the efficacy of Cissus quadrangularis paste on fracture healing in artificially induced fractured rabbits. Methods: Fifteen rabbits were separated into three groups namely A, B, and C. Veldt grape paste was applied in groups B and C (Treatment Group) by close reduction and open reduction methods of fracture management; respectively, while group A was kept as control. The blood parameter and fracture healing properties in all animals have been monitored and examined routinely during the study period. Results: Both treated groups revealed lower serum calcium levels (SCL) than the control group after 24 hours of fracture that became within the normal range on the 14th day. Fracture healing in the treated groups has been commenced more rapidly than the control group with complete bridging of discontinuity by a distinct osseous callus in the fracture line on day 7 and complete effacing of fracture line on day 14. Conclusion: We did not find any type of anomalousness, clinical deviations, and alteration of serum calcium level on the 14th day of the fracture in treated animals hence Veldt Grape paste could be readily applicable to the management of the fracture in animals.
\end{abstract}

Keywords: Cissus quadrangularis; Fracture Healing; Veldt Grape.

\section{Resumo}

Objetivos: avaliar a eficácia da pasta de Cissus quadrangularis na consolidação de fraturas em coelhos fraturados artificialmente. Metodos: quinze coelhos foram separados em três grupos (A, B e C). A pasta foi aplicada nos grupos B e C (Grupo de Tratamento) pelos métodos de redução fechada e redução aberta de gerenciamento de fraturas; respectivamente. 0 grupo A foi mantido como controle. 0 parâmetro sanguíneo e as propriedades de cicatrização de fraturas em todos os animais foram monitorados e examinados, rotineiramente, durante o período do estudo. Resultados: ambos os grupos tratados revelaram níveis séricos de cálcio (SCL) mais baixos do que o grupo controle, após 24 horas de fratura que se tornou normal no 14을. A cicatrização da fratura nos grupos tratados foi iniciada mais rapidamente do que o grupo controle, com ponte completa de descontinuidade por um calo ósseo distinto na linha de fratura no dia 7 e apagamento completo da linha de fratura no dia 14. Conclusao: não encontramos nenhum tipo de anomalia, desvios clínicos e alteração do nível sérico de cálcio no $14^{\circ}$ dia da fratura nos animais tratados, portanto, a pasta Veldt Grape pode ser aplicável ao manejo da fratura em animais.

Palavras-chave: Cissus quadrangularis; Cicatrização de fratura; Uva Veldt.

\section{INTRODUCTION}

Surgical disorders including fractures are the most important causes of animal fatality, which causes a huge economic loss because of culling and slaughtering the productive animals ${ }^{1}$. The surgical disorders also decrease the growth, performance, and economic value of food-producing animals largely ${ }^{2}$. The majority of farmers in developing countries rely on traditional medicine for the diseases, disorders, and injuries of their livestock. Thousands of medicinal plants throughout the world are a chief natural resource of indigenous medicine, have been utilizing for that purpose since ancient times ${ }^{3}$. Since antiquity, people have been using plants as a leading source for medicines to subside the various form of infection, illness, and infirmity. The World Health Organization announced that $80 \%$ of the world's population relies on medicinal plants and traditional therapies involve the use of plant extract's active constituents ${ }^{4}$. The attentiveness of practitioners to medicinal plants has been expanding day by day, as they are deemed to be impregnable and less expensive than the synthetics ${ }^{5}$. Ethnopharmacology plays a crucial role in the advancement of plant medicine. A lot of research by ethnobotanists, ethnopharmacologists, physicians, and phytochemists is the main resource to the progress of plant medicine ${ }^{6}$. Traditional medicinal practitioners over the world still rely on plants as their main resource to treat various ailments and anomalousness, and this knowledge of the practitioners is inter-generational and passed on from one generation to others.

Research on different medicinal plants has been conducted in Bangladesh over the last few years7-10. The demand for these plants is expanding now a day among physicians and health practitioners but research on medicinal plants in veterinary medicine is scanty throughout the world including Bangladesh.

Correspondence: Nasrin Sultana Juyena. Department of Surgery and Obstetrics, Bangladesh Agricultural University, Mymensingh-2202, Bangladesh. E-mil: juyenahabib@yahoo.com

Conflict of interest: The authors declare that there is no conflict of interest.

Received: 2021 Jan 14; Revised: 2021 Nov 27; Accepted: 2022 Jan 14 
The uses of plant medicine are more effective where farmers have very few facilities of modem treatment for their livestock and many farmers cannot afford the cost of treatment; hence, it is essential to treat the fracture economically with success.

Veldt Grape is a vining plant native to India and Africa that has been used medicinally for centuries in these regions by traditional practitioners. A lot of research has been conducted globally on the efficacy of Cissus quadrangularis including, its anti-inflammatory effects ${ }^{11-12}$, anti-osteoporotic effects ${ }^{13}$, Antioxidant activity ${ }^{14}$, and effects on skeletal systems ${ }^{15}$. Pandit et al. (2020) reported the antifungal effects of Cissus quadrangularis extract on onchomycosis rather than fluconazole ${ }^{16}$. The plant is used in traditional medicine in the treatment of different types of diseases and disorders for its high amounts of Vitamin C, cartotene, and anabolic steroid substances ${ }^{17}$. Due to the presence of these medicinal substances including antioxidant, antifungal, and antibacterial effects of Cissus quadrangularis extract, it could be an effective option in the treatment of a fracture. Kasthe et al. (2020), examined the synergistic effect of Cissus quadrangularis callus extract and graphene oxide in bone regeneration and bone tissue engineering and they found that these extracts enhanced the osteoblastic differentiation, osteoconduction, and osteoinduction18. Deka et al., (1994), reported the healing effects of Cissus quadrangularis methanolic extract on experimentally induced fractured dog19. Most of the researchers reported the effects of Cissus quadrangularis extract, however, scientific research on the uses of Cissus quadrangularis paste in the fracture management of animals is crucial. No published data is available on the uses of Veldt Grape paste in veterinary medicine to manage fracture and bone healing. Considering the above facts and situations, the present study was performed. The study will reveal the efficacy of Cissus quadrangularis paste and its uses in veterinary surgical practices that will be helpful for future researchers throughout the world in this field of research.

\section{MATERIALS AND METHODS}

Fifteen rabbits between 4 and 6 months of age with bodyweight 2.5-3.5 kg, free from any physical, neurologic, metabolic, or infectious diseases were selected and divided into three groups named $\mathrm{A}$ as the control group, $\mathrm{B}$ and $\mathrm{C}$ were experimental groups. We collected the Veldt Grape plant from the local area of Bangladesh, cleaned it with saline water and cut it into small pieces, made a paste by crushing and grinding them with sterile mortar and pestle.

\section{Ethical Approval}

To perform the animal experiments, we had institutional ethical approval from the approval committee. The approval no. is AWEEC/BAU/2020(16).

\section{Induction of fracture}

Rabbits were anesthetized by Diazepam (Sedil ${ }^{\circledR}$, Square
Pharmaceuticals Ltd. Dhaka, Bangladesh) for sedation at the rate of $2 \mathrm{mg} / \mathrm{kg}$ body weight IM. After five minutes of sedation, ketamin $\mathrm{HCl}$ (G-Ketamine ${ }^{\circledR}$, Gonosasthaya Pharmaceuticals Ltd, Bangladesh) was injected at the rate of $30 \mathrm{mg} / \mathrm{kg}$ body weight IM. After 3-5 min, animals become unconscious. Then selected limb was clipped, shaved, and painted with the antiseptic (Povin ${ }^{\circledR}$, Opsonin Pharmaceuticals Ltd., Bangladesh). A close fracture in radius-ulna of the right or left forelimb has been produced in each rabbit by bending either end of the bone in hands.

\section{Management of fracture}

In group A, after controlling the animal, the fractured part was palpated by hand. The extension and counter extension (traction) was applied to keep the two ends of the fractured limb in proper apposition and placed three splints around the fractured part; the first splint on the fractured site was turned over with gauze, other splints on other sides, and rolling with gauze. In group B, we applied Veldt Grape paste surrounding the fractured site and supported by splints over that area ${ }^{20}$. In the case of group $\mathrm{C}$, made an incision (depending on the position of fracture), skinned by blunt dissection, removed all tissue debris, bone fragments, and exudates, and then washed with normal saline. $(0.9 \% \mathrm{NaCl})$. To stop bleeding we ligated the major artery and vein with chromic catgut no. 3-0 (Ethicon ${ }^{\circledR}$, Medsurge Ind. Pvt. Ltd., India). Internal fixation was executed by using wire suture, in the case of oblique fracture; fracture fragments were fastened together with fullcirclage stainless steel wire. In certain cases, hemicerclage wire suture is also used. Muscle and fascia were sutured using catgut 3-0. The skin was closed by using the horizontal mattress or a simple interrupted pattern with nylon. To give additional support to the limbs and for immobilization, we used a bamboo splint in all cases.

\section{Post-Operative Care and Observation}

Systemic antibiotic Oxytetracycline (Renamycin $100^{\circledR}$ Reneta Limited) at the rate of $15 \mathrm{mg} / \mathrm{kg}$ body and analgesic injection, Ketoprofen (Inj. Kop Vet $^{\circledR}$ Square Pharmaceuticals Ltd. Bangladesh) at the rate of $3 \mathrm{mg} / \mathrm{kg}$ Bodyweight intramuscularly daily for 3 days to subside post-operative pain in Group A. No medication was applied in groups B and C. The animals were entirely cramped to their stalls and only limited movement was permitted. We recorded temperature, heart rate, respiration rate before and after induction of fracture up to the fifth postoperative day.

\section{Blood Collection}

We collected blood from the heart directly before fracture and after 24 hours, at day 7 and day 14 of fracture from each group, prepared serum, and measured serum calcium level by Olympus AU680 Random Access Multbatch Chemistry Analyzer. Radiographic Examination

Routine radiographic examinations were done to elucidate 
the actual condition of fracture and healing, immediately after induction of fracture, on the 7th and 14th day of fracture respectively. We radiographed lateral (right lateral-RL or Left lateral- LL position) views of the affected bones and placed $X$-ray cassette under the limb to be radiographed, then selected exposure factors; kV-85, mA-50, s-0.05, and processed X-ray films manually. $X$-ray film viewer monitored all radiographs.

\section{RESULTS}

We documented all clinical parameters, serum calcium level, and radiographic results to divulge the efficacy of paste on bone healing. The clinical observations viz. rectal temperature, heart rate, and respiration rate were documented daily for the first five consecutive days. Rectal temperature, heart rate, and respiratory rate increased significantly $(p>0.05)$ up to the third day of fracture and then decreased to normal physiological range in all experimental animals

\section{Serum calcium level}

The SCL of treated groups was reduced largely after 24 hours of fracture than that of the control group and the reduction of $\mathrm{SCL}$ was higher in Group C (8.60- $\pm 0.20 \mathrm{gm} / \mathrm{dl})$ compared to group B. It was slightly increased on the 7th day and become in normal physiological range on 14th days of fracture in all groups. Finally, SCL was the highest $(11.92 \pm 0.24 \mathrm{gm} / \mathrm{dl})$ in Group C than that of other groups after complete healing of fracture (Table 1 ).

Table 1. Serum calcium level of the Rabbit

\begin{tabular}{lrrrr}
\hline $\begin{array}{l}\text { Treatment } \\
\text { group }\end{array}$ & \multicolumn{4}{c}{ Serum calcium level of the Rabbit (mg/dl) } \\
\hline Before & $\begin{array}{r}\text { After } 24 \\
\text { hours of } \\
\text { fracture }\end{array}$ & $\begin{array}{r}\text { After } 7 \text { days } \\
\text { of fracture }\end{array}$ & $\begin{array}{r}\text { After } 14 \\
\text { days of } \\
\text { fracture }\end{array}$ \\
\cline { 2 - 5 } A & $10.2 \pm 0.20$ & $9.5 \pm 0.23 a$ & $9.8 \pm 0.22 \mathrm{a}$ & $9.9 \pm 0.19 \mathrm{a}$ \\
B & $10.4 \pm 0.17$ & $8.8 \pm 0.16 \mathrm{~b}$ & $9.2 \pm 0.23 \mathrm{~b}$ & $10.5 \pm 0.26 \mathrm{~b}$ \\
C & $10.3 \pm 0.16$ & $8.6 \pm 0.20 \mathrm{~b}$ & $9.1 \pm 0.21 \mathrm{~b}$ & $11.9 \pm 0.24 \mathrm{c}$ \\
\hline
\end{tabular}

\section{Radiographic examination}

Radiography was performed immediately after fracture, on the 7th and the 14th day of fracture. Complete fractured bone in radiography was diagnosed by observing a break in the continuity of a bone indicated by a line of radiolucency during the distraction of fragments. Complete fractures of all rabbits have been observed and confirmed. Incomplete alignment and fracture were easily visible in radiographs of the control group. On the 14th day, incomplete osseous callus was observed and the fracture was not completely repaired in the control group. We found proper healing of fracture gap by a well-organized and distinct osseous callus in fracture line indicated as a line of radiopacity on day 7 in Group B \& C. On day 14, the radiograph revealed complete effacing of fracture line with well osseous callus in all rabbits of Group B \& C.

\section{Toxicity of Cissus quadrangularis extracts}

None of the rabbits presented signs of abnormalities during two weeks of experimental periods. Therefore, the extract did not produce any toxicity throughout the experiment.

\section{DISCUSSION}

Growth, performances, production, and reproduction of domestic and pet animals are hinders by different diseases and disorders, the fracture and mechanical injury are the leading causes of orthopedic disorders ${ }^{21}$. The healing of bone fracture is the only marvelous restoration process without the formation of any scar tissue and restore of the tissue to its actual form without any anomalousness. The present study was executed with the objectives to evaluate the effect of veldt grape paste on fracture healing in the experimentally induced fractured rabbit. Deka et al., (1994) reported the effects of C. quadrangularis on fracture healing in experimentally induced fractured dogs and they used the extract internally to the animal by subcutaneous route19. However, the main benefit of plant medicine for fracture healing is its external use in various forms, which shows amazing results in decreasing pain and healing fractures. We used the paste form of the plant and applied it externally to the laboratory animals to examine its effects on fracture healing. We used rabbits as experimental animals to reduce the research cost, they are easy to handles due to small in size and good temperament and are readily available ${ }^{22}$.

Rectal temperature, heart rate, and respiratory rate increased to a significant level ( $p>0.05$ ) in all rabbits immediately after fracture up to the third day and then become normal in next day. Elevated body temperature indicates fever due to the absorption of necrotic debris around the site of trauma or inflammation in the operative $s^{2} \mathrm{e}^{23}$. The SCL of treated groups was reduced drastically after 24 hours of fracture than that of the control group and this reduction was higher in group $\mathrm{C}$ (8.60 $\pm 0.20 \mathrm{mg} / \mathrm{dl}$ ) compared to groups $\mathrm{A}$ and $\mathrm{B}$. The decrease in SCL to a greater extent in the treated group may be due to a faster healing process with the quick mobilization of calcium from serum to the bony tissue to form callus19. The concentration of calcium \& phosphate in the serum \& extracellular fluids in a maximum amount helps to precipitate calcium-phosphate crystals to build new osteoid, causing it to harden and formation of strong bone ${ }^{24}$.

Splint and bandage were used for close reduction group and external fixation without veldt paste in the control group. The outcome was associated with delayed healing in most cases. We found complete healing of fracture with a line of radiopacity on day 7 and fracture line was effaced perfectly on day 14 in Group B \& C; respectively. Hence, the veldt grape causes rapid healing of the fracture and corresponds well with the findings of Srivastava et al. $(2011)^{25}$. Cissus quadrangularis contains different types of vitamins including vitamin C, carotinoids, and steroids17 which affect bone healing by influencing rapid regeneration of connective tissues in the healing and 
mineralization26. Cissus quadrangularis affects osteoblast differentiation and mineralization, it also exhibits antiosteoporotic activity in osteoblasts. The phytogenic steroidal effects of Cissus quadrangularis are responsible for its biological activity on bone healing ${ }^{13}$.

Because of the simplicity of the techniques, we selected the internal fixation technique with wire sutures in the present study. Proper reduction and alignment of fractured ends have been confirmed in all rabbits immediately after the fracture stabilization. All rabbits showed good weight-bearing in the immediate post-operative period and could lie down, stand, and walk freely with the fixator without any difficulties after 14 days.

Scientists used wire sutures in the form of fullcerclage and hemicerclage systems in the treatment of fractures in $\operatorname{dogs}^{20}$. Fullcerclage wires are useful in long oblique fractures, spiral fractures, or in fractures that have longitudinal cracks. Cerclage wire is normally supported by additional implants (e.g., IM pins, external fixators, and plates) to control the large bodyweight (primarily bending) forces. In the case of more than one fragment, or insufficient fracture length, cerclage wire can only be used to hold fragments in position; it cannot generate the compression for weight-bearing loads. The attempt to gain stability with cerclage wire in such types of fractures could be cerclage wire failure ${ }^{27}$.

In this study, the internal fixation system has been assembled by the type and position of fracture, to minimize the potential failure rate of the operation. Stainless wires of small diameter are effective to maintain rigid fixation with minimum traumatic effect $^{27}$. We ensured adequate firmness and evaded angulation properly also used splint for external support of the animals. The solidity of the limb ease the care of soft tissue and was most helpful to evade greater complications.

For proper monitoring, we radiographed the affected bones in lateral views on days seven and 14 , after surgery to assess the reduction, and alignment of bone fragments, callus formation and the existence of periosteal reaction or malformation if any. Direct fracture healing is initially characterized by the disappearance of the fracture line without the formation of an external callus. Depending on the size of animals, complete healing takes a few months to a few years, during which the fracture site will remain radiolucent compared with the intact cortex28. We did not find any hindrance in rabbits treated with veldt paste in this study and it can be reported that the prognosis of fractures is competent in most of the rabbits. Normally, treatment type especially, fixation type (internal, external) has marked effects on complications involving improper fracture healing, infection, damage to soft tissue, or chronic lameness with different types of abnormalities such as angular deformity, non-union and osteomy0elitis can cause the treatment failure in comminuted, open and infected fractures ${ }^{27}$.

It is important to mention that no antibiotic was used in the treatments of rabbits in treated groups. This is in agreement with the findings of Panpimanmas et al. $(2010)^{29}$. Scientists reported that Cissus quadrangularis has significant antioxidant and antimicrobial activities ${ }^{14}$. Another researcher reported its antifungal activity ${ }^{16}$. The combined effects of antibacterial, antifungal, and antioxidant activity of this plant could be beneficial in fracture healing. The rabbit is contemplated as a good animal model to research with before examining fracture management and related experiment in a larger animal mode ${ }^{122}$. Therefore, the complete histopathological study might be helpful to observe the effect of Cissus quadrangularis on tissue reaction and the normal histochemical parameters in fractured animals. Complete biochemical analysis and a longer-term study in farm animals are acknowledged to establish the safe use of the Cissus quadrangularis at the field level for the treatment of fracture in animals.

\section{CONCLUSION}

The results of this study indicate that the Cissus quadrangularis extract contains substances that possess an effect on bone healing in fractured animals. So, Cissus quadrangularis is the effective treatment option for fractured animals and is convenient in comparison to other chemical treatments due to fewer side effects and low cost of treatment

\section{REFERENCES}

1. Berge $C$ and Westhues TS. Veterinary Operative Surgery. Denmark: Medical Book Company, Bonleverd; 1998. 148p.

2. Hossain MA, Shahidullah M and Ali MA). Surgical disease and reproductive disorders recorded at the Veterinary Hospital of Bangladesh Agricultural University, Mymensingh. Bangladesh. Bang Vet J. 1986; 20:1-5.

3. Ahmad I, Mehmood Z, Mohammad. Screening of some Indian medicinal plants for their antimicrobial properties. J. Ethnopharmacol. 1998 Sep; 62(2): 183-193. doi: 10.1016/s0378-8741(98)00055-5.

4. World Health Organization. Summary of WHO guidelines for the assessment of herbal medicines. Geneve: WHO; 1993.

5. Yusuf MA and Wahab MD Some Tribal Medicinal plants of Chittagong Hill Tracts, Bangladesh. Bangl J Plant Taxon. 2007; 14(2): 117-128. doi: 10.3329/bjpt. v14i2.531.
6. Gilani AH, Yaeesh S, Jamal Q, Ghayur MN. Hepatoprotechtive activity of aqueous-methanol extract of Artemisia vulgaris. Phytother Res. 2005 Feb; 19(2): 170-172. doi: 10.1002/ptr.1632.

7.Das PR, Islam MT, Mahmud ASMSB, Kabir MH, Hasan ME, Khatun Z, Rahman MM, Nurunnabi M, Lee YK, Jahan R, Rahmatullah M. An ethnomedicinal survey conducted among the folk medicinal practitioners of three villages in Kurigram district, Bangladesh. Amer Eur J Sus Agr. 2012 Apr; 6(2): 85-96.

8. Hasan ME, Akter S, Piya NS, Nath PK, Nova UHR, Choudury HR. Variations in selection of medicinal plants by tribal healers of the Soren clan of the Santal tribe: a study of the Santals in Rajshahi district, Bangladesh. Amer Eur J Sust Agri. 2012; 6 (4): 315-324.

9. Khan MA, Hasan MN, Jahan N, Das PR, Islam MT, Bhuiyan MSA. Ethnomedicinal wisdom and famine food plants of the Hajongcommunity of Baromari village in Netrakona district of Bangladesh. Amer Eur J Sust Agri. 2012 Jan; 6: 387-397. 


\section{Effect of Cissus quadrangularis on Fracture Healing in Laboratory Animal}

10. Sarker B, Akther F, Ayman U, Sifa R, Jahan I, Sarker M, Chakma SK, Podder PK, Khatun J, Rahmatullah M. Ethnomedicinal investigations among the Sigibe clan of the Khumi tribe of Thanchi sub-district in Bandarban district of Bangladesh. Amer Eur J Sust Agri. 2012 Jan; 6(4): 378-386.

11. Banu J, Varela E, Bahadur AN, Soomro R, Kazi N, Fermandes G. Inhibition of bone loss by Cissus quadrangularis in mice: a preliminary report. J Osteoporos. 2012; 2012: 101206. doi: 10.1155/2012/101206.

12. Nie TW, Shukkoor MS, Nair RS, Amiruddin FK, Ramassami S. Involvement of opioidergic and serotonergic systems in the analgesic activity of Cissus quadrangularis L. stem extract in mice. J Basic Clin Physiol Pharmacol. 2015 Jan; 26(1): 35-41. doi: 10.1515/jbcpp-2014-0035.

13. Potu BK, Bhat KM, Rao MS. Petroleum ether extract of Cissus quadrangularis (Linn.) enhances bone marrow mesenchymal stem cell proliferation and facilitates osteoblastogenesis. Clinics (Sao Paulo). 2009; 64(10): 993-998. doi: 10.1590/S1807-59322009001000010.

14. Lekshmi RK, Rajesh R and Mini S. Ethyl acetate fraction of Cissus quadrangularis stem ameliorates hyperglycaemia-mediated oxidative stress and suppresses inflammatory response in nicotinamide/ streptozotocin induced type 2 diabetic rats. Phytomedicine. 2015 Sep; 22(10): 952-960. doi: 10.1016/j. phymed.2015.06.014.

15. Bhagat PK, Kumar MRB, Rao SM. Petrolium ether extract of Cissus quadrangularis enhance bone marrow mesenchymal stem cell proliferation and facilitates osteoblastogenesis. J Clin Sao Paulo. 2009; 64(10): 10. doi: https:// doi.org/10.1590/S1807-59322009001000010.

16. Pandit AP, Kedar AA, Ranaware SV, Khandelwal KR. Antifungal Nail Lacquer Loaded with Extract of Cissusquadrangularis for Treatment of Onychomycosis. Indian J Pharm Educ Res. 2020; 54(2s): s269-s275. doi:10.5530/ijper.54.2s.83.

17.Murthy KNC, Vanitha A, Swamy MM, Ravishankar GA. Antioxidant and antimicrobial activity of Cissus quadrangularis L. J Med Food. 2003; 6(2): 99105. doi: 10.1089/109662003322233495.

18. Kashte S, Sharma RK, Kadam S. Layer-by-layer decorated herbal cell compatible scaffolds for bone tissue engineering: A synergistic effect of graphene oxide and Cissus quadrangularis. J Bioact Compat Pol. 2020 Jan; 35:
57-73. doi: https://doi.org/10.1177/0883911519894667.

19. Deka DK, Lahon LC, Saika J, Mukit A. Effect of Cissus quadrangularis in accelerating healing process of experimentally fractured radius-ulna of dog: A preliminary study. Indian J Pharmacol. 1994; 26(1):44-45.

20. Alam MM, Juyena NS, Alam MM, Ferdousy RN, Paul S. Use of Wire Suture for the Management of Fractures in Calves. J Agri Vet Sci. 2014 Jan; 7(1): 90-96.

21. Gahlot TK. Selected Topics on Camelids. India: Sankhla Printers, Bikaner 2000. p. 382-407.

22. Pearce Al, Richards RG, Milz S, Schneider E, Pearce SG. Animal models for implant biomaterial research in bone: a review. Eur Cell Mater. 2007 Mar; 13: 1-10.

23. Newton CD and Nunamaker DM. Textbook of Small Animal Orthopaedics. Philadelphia: Lippincott Williams and Wilkins; 1985. 120p.

24. Michael H, Harkonen PL, Vaananen HK, Hentunen TA. Estrogenn and testosterone use different cellular pathways to inhibit osteoclastogenesis and bone resorption. J Bone Miner Res. 2005 Dec; 20(12): 2224-2232. doi: 10.1359/ JBMR.050803.

25. Srivastava AK, Srivastava P, Behera BR. Pharmacosnostical and phytochemical investigation of Cissus quadrangularis Linn stem. Int. J. Pharm Res Dev. 2011; 11: 207-215. http://ijprd.com/March 11 Issue.html

26. Hulse D, Hyman B. Fracture biology and biomechanics. Textbook of Small Animal Surgery. Philadephia: WB Saunders; 1993.

27. Olcay B, Bilgili $H$ and Kürüm. Treatment of communitive diaphyseal metacarpal fracture in a calf using the llizarov circular external fixation system. Israel J Vet Med. 1999; 54:122-127. Original não localizado.

28. Rahn BA. Bone healing: histologic and physiologic concepts. Stuttgart New York: Thieme. 2002; 287-326.

29. Panpimanmas S, Sithipongsri S, Sukdanon C. Experimental comparative study of the efficacy and side effects of Cissus quadrangularis L. (Vitaceae) to daflon (Servier) and placebo in the treatment of acute hemorrhoids. J Med Assoc Thai. 2010 Dec; 93(93): 1360-1367.

How to cite this article/Como citar este artigo :

Zahan N, Hasan M, Mallick S, Hashem MA, Juyena NS. Effect of Cissus quadrangularis on Fracture Healing in Laboratory Animal. J Health Biol Sci. 2022; 10(1):1-5 